\title{
Local Effect of Intramuscular Injection of Meloxicam and Diclofenac: An Experimental, Comparative and Histological Study
}

\author{
Ahmed Hisham Qassim*, Omar Riadh Hamdi* , Ashraf Abdulraheem Ayoob*, Mohammed Taib Taher \\ *Department of Anatomy, Histology and Embryology, College of Medicine, University of Mosul, Mosul, Iraq. \\ Correspondence:ahkassim76@gmail.com
}

(Ann Coll Med Mosul 2019; 41 (2):163-169).

Received:17 ${ }^{\text {th }}$ Oct. 2019; Accepted: 15 $5^{\text {th }}$ Dec. 2019.

\section{ABSTRACT}

Objectives: To compare the local effect of therapeutic doses of meloxicam and diclofenac on the muscle of rats at different periods by intramuscular injection.

Materials and methods: Thirty six adult albino rats were divided equally into 6 groups. The $1^{\text {st }}$ and $2^{\text {nd }}$ groups were injected intramuscularly with normal saline for 2 and 4 weeks respectively, the $3^{\text {rd }}$ and $4^{\text {th }}$ groups were injected intramuscularly with meloxicam for 2 and 4 weeks respectively, the last 2 groups were injected intramuscularly with diclofenac sodium also for 2 and 4 weeks respectively. The drugs were injected into the quadriceps femoris muscle of the right femur once each day till the end of the period stated. The specimens were histologically processed, stained with hematoxylin and eosin and examined with light microscope.

Results: No changes were seen in quadriceps femoris muscles of groups 1, 2, 3 and 4, whereas group 5 showed congested blood vessels within normal muscle tissue. In Group 6 mononuclear inflammatory cells infiltration, vascular congestion, fibrosis, degenerative changes and muscle tissue necrosis were seen.

Conclusion: Meloxicam is safer than diclofenac sodium on muscular tissue after a long-term daily intramuscular injection.

Keyword: meloxicam, diclofenac, intramuscular injection, muscle tissue.

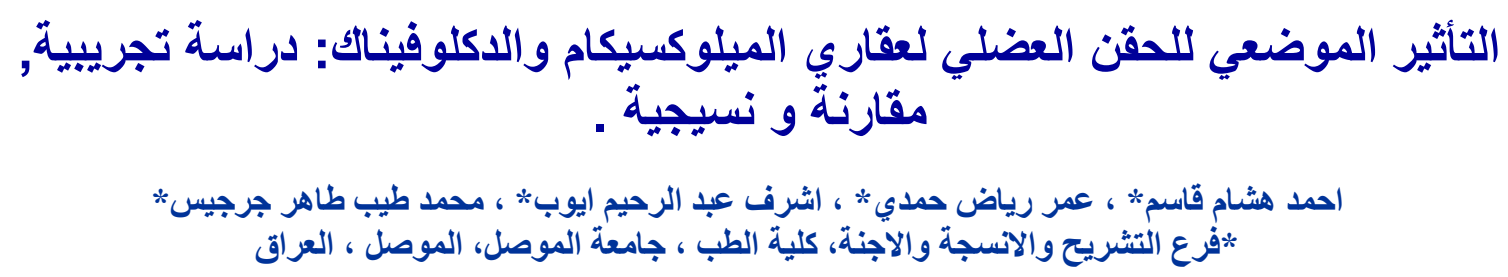

الخلاصة

الهـف من الاراسة: دراسة مقارنة التأثير الموضعي للجرع العلاجية لعقاري الميلوكسيكام والدكلوفيناك صوديوم على عضلة

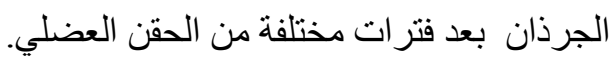

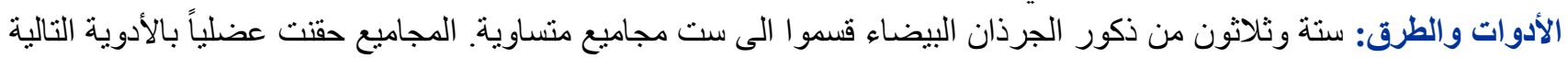

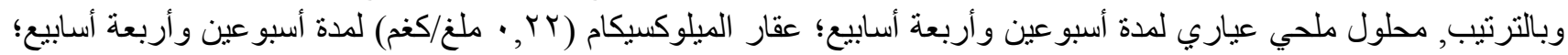

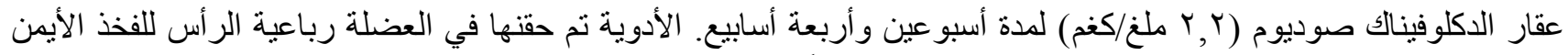

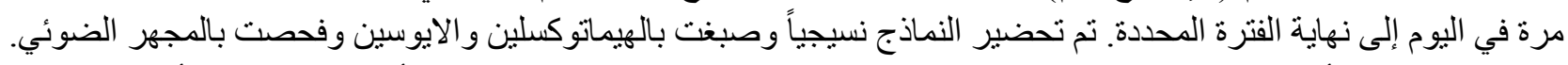

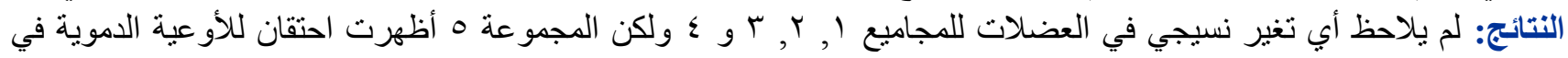

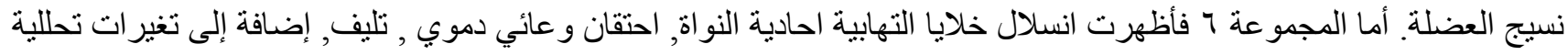
ونخر في النسيج العضلي. الاستنتاج: عقار الميلوكسيكام أكثر أماناً من عقار الدكلوفينالك صوديوم على النسيج العضلي بعد فترة طويلة من الحقن العضلي اليومي. 


\section{الكلمات المفتاحية: ميلوكسيكام, الدكلو فينالك صوديوم, الحقن العضلي, النسيج العضلي.}

\section{INTRODUCTION}

ystemic and topical nonsteroidal anti$\checkmark$ inflammatory drugs(NSAIDs) are the most commonly prescribed drugs in the treatment of inflammation and pain associated with chronic inflammatory conditions like rheumatoid arthritis and osteoarthritis ${ }^{1-5}$. They reduce inflammation by reducing prostaglandin synthesis through inhibition of cyclooxygenase enzyme $(\mathrm{COX})^{6}$. COX-1 and COX-2 are isoforms of the enzyme, suppression of COX-2 is responsible for the therapeutic gain of NSAIDs, while their adverse effects result from inhibition of $\mathrm{COX}-1^{7}$.

The route of administration of NSAIDs is considered to be an important field for investigation, because these drugs can be given orally, intramuscularly, rectally and intra-articularly in addition, they can be applied locally on mucosa and $\operatorname{skin}^{8-10}$. Thus a lot of researches had been carried out with results showing that intramuscular administration had some advantages over oral route in that it has faster onset of action, avoids first pass metabolism, besides, it prevents direct contact of the drug with gastric mucosa ${ }^{8,11-14}$. On the contrary, intramuscular route can cause tissue necrosis at the site of injection even after a short term use ${ }^{15,16}$.

Since meloxicam is a preferentially selective COX-2 inhibitor, whereas diclofenac sodium is a nonselective COX inhibitor ${ }^{17,18}$. several researchers had studied the efficacy, tolerability, as well as the safety of meloxicam and compared it with diclofenac after a short period of intramuscular injection or after a long period of oral administration in both experimental animals and humans ${ }^{19-22}$.

The aim of the present study is to compare the local effect of therapeutic doses of meloxicam and diclofenac on rats' muscle given for the same periods as an intramuscular injection.

\section{MATERIALS AND METHODS}

\section{Animals}

Thirty six male adult albino rats were obtained from the animal house of Experimental Research Unit, College of Medicine, University of Mosul, Iraq. The animals were kept in the laboratory in special plastic cages under ideal conditions. The number of animals in each cage was three. Food and water were available ad libitum throughout the study.

\section{Drugs}

Meloxicam $\quad\left(\right.$ Mobic $^{\circledR}$, Boehringer Ingelheim, Germany) and diclofenac sodium $\left(\right.$ Refen $^{\circledR}$, Hemofarm, Serbia) in the form of ampoules were purchased from a common commercial supply (Alradwan drug store). The drugs were administered in therapeutic doses similar to that given to human ${ }^{23}$. Which were calculated by diluting the drugs with normal saline. ${ }^{(24)}$ The drugs were injected intramuscularly into the quadriceps femoris muscle of the right femur of the rat every day till the end of the stated period according to the subdivided groups.

\section{Groups And Experimental Design}

After one week of acclimatization, the animals were divided into six groups, each consisted of six rats.

\section{Control Groups}

Groups 1 and 2: received a single daily intramuscular injection of normal saline $(1 \mathrm{ml} / \mathrm{Kg})$ for 2 and 4 weeks respectively.

\section{Treated Groups}

-Group 3: animals received a single daily intramuscular injection of $0.22 \mathrm{mg} / \mathrm{kg}$ of meloxicam for 2 weeks.

-Group 4: is similar to that of group 3, but the drug is given for 4 weeks.

-Group 5: rats were daily intramuscularly injected with a single dose of diclofenac sodium $(2.2 \mathrm{mg} /$ $\mathrm{kg}$ ) for 2 weeks.

-Group 6: is similar to that of group 5, but the drug is given for 4 weeks.

Twenty four hours after the last injection, rats were killed by inhaling overdose of Ether. Dissection of the right hind limbs was done and the quadriceps femoris muscle was removed from each animal and prepared for histological processing. 


\section{Histological Study}

The quadriceps femoris muscle tissue samples were fixed in $10 \%$ neutral buffered formalin for 24 hours, then they were dehydrated, cleared, embedded in paraffin and sectioned by the microtome into sections of $5 \mu \mathrm{m}$ thickness, thereafter the sections were mounted on glass slides and stained with hematoxylin and eosin. The histological slides were examined through Olympus light microscope, and several sections were chosen to obtain their photographs using a digital camera.

\section{RESULTS}

\section{Control (Untreated) Groups:}

In groups 1 and 2, the histological changes in the muscular biopsy were unremarkable (Figure 1).

\section{Treated Groups}

In groups 3 and 4, microscopic examination was similar to that of control groups (Figure 2).

In animals of group 5, the histological finding was only congested skeletal muscle fibers(Figure 3 ).

However, in group 6, the histological sections revealed mononuclear inflammatory cells infiltration, vascular congestion, fibrosis, degenerative changes and muscle tissue necrosis. Moreover, several areas showed hemorrhage which could be of traumatic origin (Figures 4 and 5, Table 1).

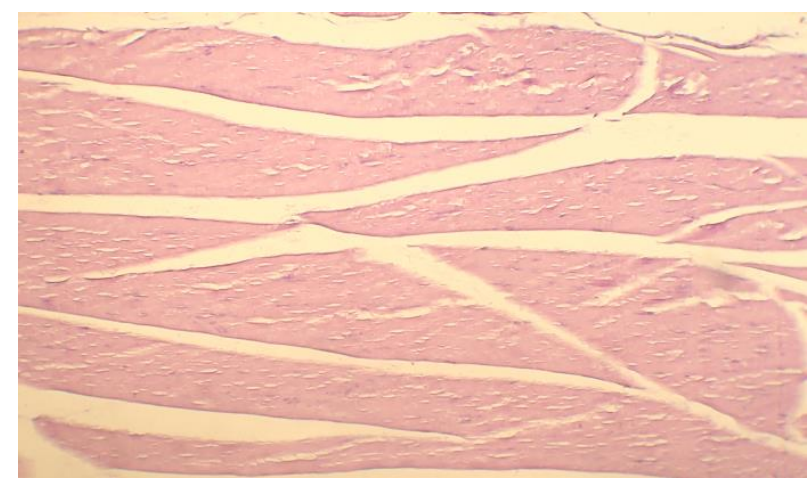

Figure 1: Photomicrograph of quadriceps femoris muscle of control groups showing normal morphology. (H\&E X 100).

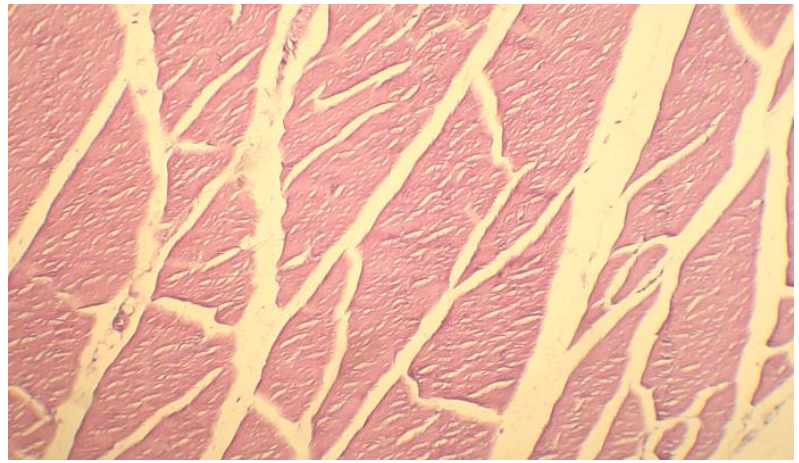

Figure 2: Photomicrograph of quadriceps femoris muscle of group 4 showing normal morphology. (H\&E X 100).

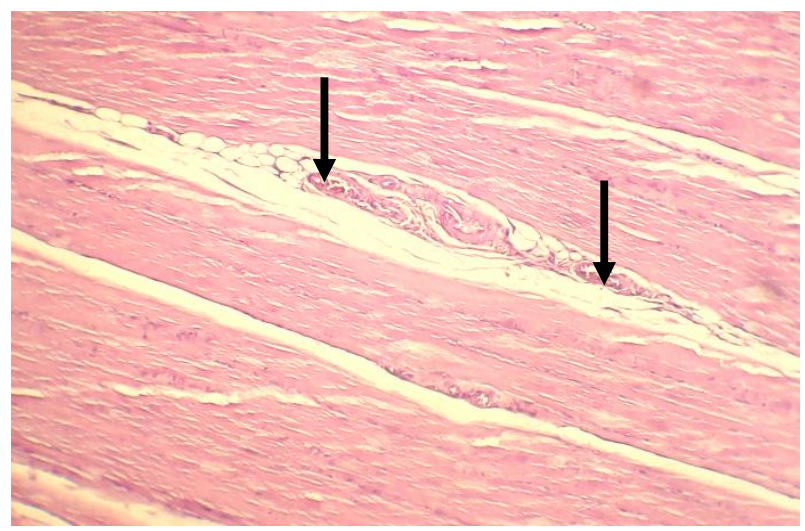

Figure 3: Photomicrograph of quadriceps femoris muscle of group 5 showing congested blood vessels within normal muscle tissue (arrows). (H\&E X 100).

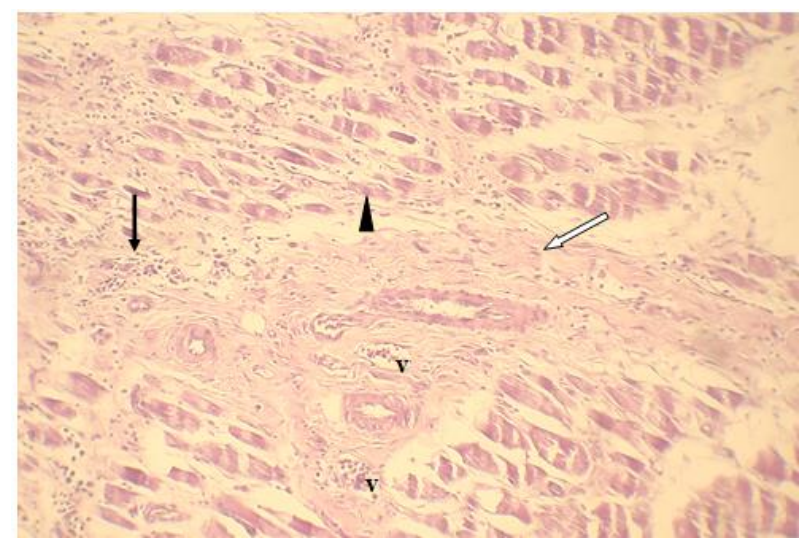

Figure 4: Photomicrograph of quadriceps femoris muscle of group 6 showing mononuclear inflammatory cells infiltration (black arrow), vascular congestion (v), fibrosis (white arrow) and degenerative changes of muscle tissue (arrowhead). (H\&E X 100). 


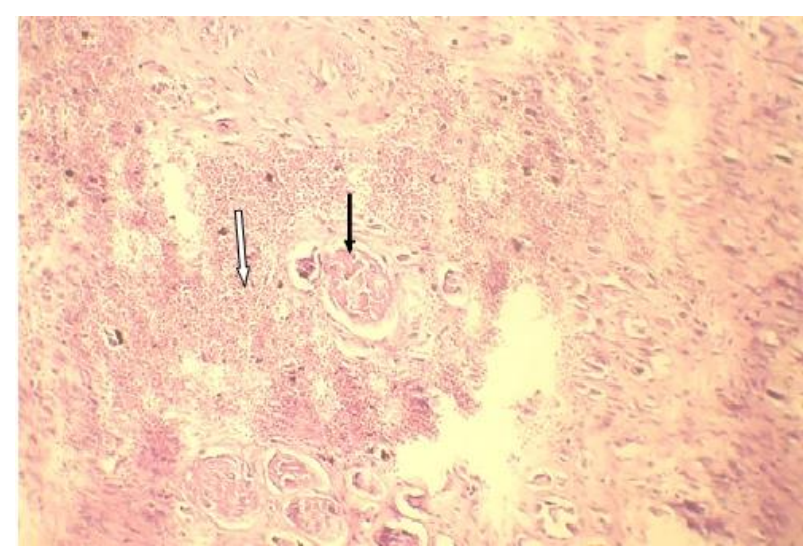

Figure 5: Photomicrograph of quadriceps femoris muscle of group 6 showing muscle tissue necrosis (black arrow) and hemorrhage (white arrow). (H\&E X 100).

Table 1: Showing drugs administered with their doses and duration of administration, as well as, histological changes of quadriceps femoris muscle obtained in different groups.

\begin{tabular}{|c|c|c|c|c|}
\hline Groups & $\begin{array}{l}\text { Drug } \\
\text { administered }\end{array}$ & $\begin{array}{l}\text { Dose of the } \\
\text { drug }\end{array}$ & $\begin{array}{l}\text { Duration of } \\
\text { administrati } \\
\text { on }\end{array}$ & Histological changes of muscle \\
\hline Group 1 & Normal saline & $1 \mathrm{ml} / \mathrm{kg}$ & 2 weeks & Normal muscle tissue \\
\hline Group 2 & Normal saline & $1 \mathrm{ml} / \mathrm{kg}$ & 4 weeks & Normal muscle tissue \\
\hline Group 3 & Meloxicam & $0.22 \mathrm{mg} / \mathrm{kg}$ & 2 weeks & Normal muscle tissue \\
\hline Group 4 & Meloxicam & $0.22 \mathrm{mg} / \mathrm{kg}$ & 4 weeks & Normal muscle tissue \\
\hline Group 5 & Diclofenac sodium & $2.2 \mathrm{mg} / \mathrm{kg}$ & 2 weeks & $\begin{array}{l}\text { Congestion of blood vessels within normal } \\
\text { muscle tissue }\end{array}$ \\
\hline Group 6 & Diclofenac sodium & $2.2 \mathrm{mg} / \mathrm{kg}$ & 4 weeks & $\begin{array}{c}\text { Inflammatory cells infiltration } \\
\text { Fibrosis } \\
\text { Degenerative changes and necrosis of muscle } \\
\text { tissue }\end{array}$ \\
\hline
\end{tabular}

\section{DISCUSSION}

Long term administration of NSAIDs is preferable via the oral route, however intramuscular injection is beneficial for the short term relief of renal colic, acute pain associated with rheumatological disorders, dysmenorrhea, post operative pain and neoplastic conditions ${ }^{25-27}$. Furthermore, intramuscular formulations may be used for treating patients in whom oral as well as rectal administration is not possible ${ }^{8}$.

This study demonstrates that a single daily intramuscular injection of therapeutic dose of meloxicam for 2 weeks and up to 4 weeks cause no damage to muscular tissue at site of injection. On the other hand, when diclofenac sodium is injected in a single daily therapeutic dose for 2 weeks will cause congestion of blood vessels in an otherwise normal muscle tissue, and increasing the duration of administration to 4 weeks will produce mononuclear inflammatory cells infiltration and vascular congestion associated with degenerative changes, necrosis of muscle tissue and fibrosis.

There are no observed data regarding the local histological effect of therapeutic doses of meloxicam and diclofenac on muscle tissue when used intramuscularly for period longer than one week.

Stei et $\mathrm{al}^{8}$. found that daily intramuscular injection of high doses of meloxicam and 
diclofenac sodium for one week can result in muscle tissue damage, and the damage produced by meloxicam is less in comparison to diclofenac. Furthermore, Miller et $\mathrm{al}^{28}$. observed that meloxicam when given intramuscularly in high doses for 4 days will cause minimal histological changes at site of injection. These findings in conjunction with the result of present study indicate that, meloxicam is safer than diclofenac when given intramuscularly. Moreover, many cases of muscle and skin necrosis (Nicolau syndrome) have been reported in patients who received a single intramuscular injection of diclofenac ${ }^{29-35}$. In contrast, no case of such syndrome has been recorded after meloxicam injection till now.

Sutton et $\mathrm{al}^{36}$. mentioned that muscle damage can be related to local drug concentration as well as its release from formulation and a drug with slow release has the ability to lessen muscle tissue damage. Meloxicam reaches its maximum plasma concentration 90 minutes after intramuscular injection ${ }^{37}$. whereas diclofenac reaches its maximum concentration after 20 minutes $^{38}$. Thus the above findings can explain why meloxicam causes less muscle damage in comparison with diclofenac as it has a slower release rate.

This explanation was supported by Lima and Oliveira $^{39}$. Souza et al. ${ }^{(40)}$ and Lopes et al. ${ }^{41}$. who investigated the protective effect of diclofenacloaded liposomes. They discovered that liposomes are able to reduce the rate of diclofenac release, acting as a drug reservoir, lowering diclofenac concentration in the local tissue and thus protecting the skeletal muscle from the toxic effect of the drug.

Other investigators who tried to explain the pathogenesis of muscle damage after diclofenac injection, reported that diclofenac which is a nonselective COX inhibitor, will inhibit both COX-1 and COX-2, reducing prostaglandins and resulting in vasoconstriction with subsequent ischemic necrosis ${ }^{29,31,42}$.

Paulsen et $\mathrm{al}^{43}$. stated that when only COX-2 is inhibited, COX-1 produces sufficient level of prostaglandins, maintaining good blood flow to the muscles, and this may further explain why meloxicam produces no muscular damage in this study, since it inhibits COX-2 more than COX-1 at therapeutic dose. ${ }^{(17)}$ However, this would be controversial to a study of Novak et $\mathrm{al}^{44}$. who affirmed that COX-2 activity is essential for skeletal muscle repair and growth. So the exact cause of the difference in the intramuscular tolerability between meloxicam and diclofenac sodium remains unclear and needs further research.

\section{CONCLUSION}

When meloxicam had been administered for 2 to 4 weeks, it produces no muscular damage, while diclofenac sodium causes damage to the muscle tissues. Therefore meloxicam is safer than diclofenac on skeletal muscle after a long period of daily intramuscular injection.

\section{Acknowledgement}

The authors would like to thank Dr. Hatim Abdulmajeed Al-Nuaimy (Laboratory Unit, Aljomhori Teaching Hospital, Mosul) for his kind help.

\section{REFERENCES}

1- Crofford LJ. Use of NSAIDs in treating patients with arthritis. Arthritis Res Ther. 2013; 15 (suppl 3):S2.

2- Balmaceda CM. Evolving guidelines in the use of topical nonsteroidal anti-inflammatory drugs in the treatment of osteoarthritis. BMC Musculoskelet Disord. 2014; 21:15-27.

3- Scarpignato C, Lanas A, Blandizzi C, et al. Safe prescribing of non steroidal antiinflammatory drugs in patients with osteoarthritis: An expert consensus addressing benefits as well as gastrointestinal and cardiovascular risks. BMC Med. 2015; 13:55.

4- Shin S. Safety of celecoxib versus traditional nonsteroidal anti-inflammatory drugs in older patients with arthritis. J of Pain Res. 2018; 11: 3211-9.

5- Cooper C, Chapurlat R, Al-Daghri N, et al. Safety of oral non-selective non-steroidal anti-inflammatory drugs in osteoarthritis: What does the literature say? Drug \& Aging. 2019 ; 36(suppl 1):S15-S24.

6- Hilario MOE, Terreri MT, Len CA. Nonsteroidal anti-inflammatory drugs: 
cyclooxygenase 2 inhibitors. J Pediatr(Rio J). 2006; 82 (suppl 5):S206-S12.

7- Patrignami P. Nonsteroidal anti-inflammatory drugs, COX-2 and colorectal cancer. Toxicol Let. 2000; 112-113:493-8.

8- Stei P, Kruss B, Wiegleb J, et al. Local tissue tolerability of meloxicam, a new NSAID: indications for parenteral, dermal, and mucosal administration. $\mathrm{Br} J$ Rheumatol. 1996; 35 (suppl 1):44-50.

9- Ligumsky $M$, Sestieri $M$, Karmeli $F$, et al. Rectal administration of nonsteroidal antiinflammatory drugs. Gastroenterol. 1990; 98:1245-9.

10- Lu L, Huang XW, Xie Y, et al. Clinical efficacy of intra-articular parecoxib injection for the treatment of early knee osteoarthritis. Zhongguo Gu Shang. 2019; 32(5): 418-22.

11- Combe B, Velicitat P, Garzon N, et al. Comparison of intramuscular and oral meloxicam in rheumatoid arthritis patients. Inflamm Res. 2001; 50 (suppl 1):S10-S6

12- Euller-Ziegler L, Velicitat P, Bluhmki E, et al. Meloxicam: a review of its pharmacokinetics, efficacy and tolerability following intramuscular administration. Inflamm Res. 2001; 50 (suppl 1):S5-S9.

13- Kadir F, Eling WMC, Abrahams D. Tissue reaction after intramuscular injection of liposomes in mice. Int J Clin Pharmacol Ther Toxicol. 1992; 30(10):374-82.

14- Boonstra JL, Cox SK, Martin-Jimenez T. Pharmacokinetics of meloxicam after intramuscular and oral administration of a single dose to American flamingos (phoenicopertus ruber) Am J Vet Res. 2017; 78(3): 267-73.

15- Lai M, Hang YC, Yao PC. Tissue necrosis after intramuscular administration of diclofenac: report of one case. Acta Paediatr Taiwan. 2005; 46(1):24-6.

16- Uri O, Arad E. Skin necrosis after selfadministered intramuscular diclofenac. J Plast Reconstr Aneasthet Surg. 2010; 63:e4e5.

17- Fleischmann R, lqbal I, Slobodin G. Meloxicam. Expert Opin Pharmacother.2002; 3:1-10.
18- Mengle-Gaw LJ, Schwartz BD. Cyclooxygenase-2 inhibitors: promise or peril? Mediators Inflamm.2002; 11(5):275-86.

19- Colberg K, Hettich M, Sigmund R, et al. The efficacy and tolerability of an 8-day administration of intravenous and oral meloxicam: a comparison with intramuscular and oral diclofenac in patient with acute lumbago. German meloxicam ampoule study group. Curr Med Res Opin. 1996; 13(7):36377.

20- Furst DE, Kolba KS, Fleischmann R, et. al. Dose response and safety study of meloxicam up to $22.5 \mathrm{mg}$ daily in rheumatoid arthritis: a 12 week multicenter, double blind, dose response study versus placebo and diclofenac. J Rheumatol. 2002; 29:436-46.

21- Pavelka K. A comparison of the therapeutic efficacy of diclofenac in osteoarthritis: a systemic review of randomized controlled trials. Curr Med Res Opin. 2012; 28(1):16378.

22- Inal S, Kabay S, Cayci MK, et al. Comparison of the effects of dexketoprofen trometamol, meloxicam and diclofenac sodium on fibular fracture healing, kidney and liver: an experimental rat model. Injury. 2014; 45(3):494-500.

23- Burdan F, Szumilo J, Klepacz R, et. al. Gastrointestinal and hepatic toxicity of selective and non-selective cyclooxygenase2 inhibitors in pregnant and non pregnant rats. Pharmacol Res. 2004; 50:533-43.

24- El-khishin IA, Amer MG. Possible protective role of $\mathrm{L}$-carnitine on diclofenac induced hepatotoxicity in adult male albino rats (histological, immunohistochemical and biochemical). Egypt J Histol. 2010; 33(2):34152.

25- Todd PA, Sorkin EM. Diclofenac Sodium. A reappraisal of its pharmacodynamic and pharmacokinetic properties, and therapeutic efficacy. Drugs. 1988; 35:244-85.

26- Dash A, Maiti R, Akantappa BTK, et al. Intramuscular drotaverine and diclofenac in acute renal colic: a comparative study of analgesic efficacy and safety. Pain Med. 2012; 13(3):366-71

27- Pommergaard HC, Klein M, Burcharth J, et al. Variation in postoperative non-steroidal 
anti-inflammatory use, after colorectal surgery: a data base analysis. BMC Anesthesiol. 2014; 14:18.

28- Miller KA, Hill NJ, Carrasco SE, et al. Pharmacokinetics and safety of intramuscular meloxicam in Zebra Finches (Taeniopygia gutta). J Am Assoc Lab Anim Sci. 2019; 58(5): 589-93.

29- Kim KK. Nicolau syndrome in patient following diclofenac administration: a case report. Ann Dermatol. 2011; 23(4):501-3.

30- Park HJ, Kim MS, Park NH. et al. Sonographic findings in Nicolau syndrome following intramuscular diclofenac injection: a case report. J Clin Ultrasound. 2011; 39(2):111-3.

31- Kim SK, Kim Th, Lee KC. Nicolau syndrome after intramuscular injection: 3 cases. Arch Plast Surg. 2012; 39:249-52.

32- Nayci S, Gurel MS. Nicolau syndrome following intramuscular diclofenac injection. Indian Dermatol Online J. 2013; 4(2):152-3.

33- Aynioglu A, Elicora A, Kaya S. Nicolau syndrome due to diclofenac injection. Ital Dermatol Venereol. 2016; 151(4): 452-3.

34- Adil M, Amin SS, Arif T. Nicolau's syndrome: A rare but preventable iatrogenic disease. Acta Dermatovenerol Croat. 2017; 25(3): 251-3.

35- Marcus F, Claude EV, Josephine M, et al. An exceptional cause of acute limb ischemia: Nicolau syndrome -single- center experience with 4 cases. Ann Vasc Surg. 2019; 58: 383e7-383e11.

36- Sutton SC, Evans LAF, Rinaldi MTS, et al. Predicting injection site muscle damage. II: evaluation of extended release parenteral formulations in animal models. Pharm Res. 1996; 13(10):1514-8.

37- Davies NM, Skojodt NM. Clinical pharmacokinetics of meloxicam: a cyclooxygenase-2 preferential nonsteroidal anti-inflammatory drug. Clin Pharmacokinet. 1999; 36(2):115-26.

38- Kurowski M. Pharmacokinetics and biological availability of diclofenac preparations following intramuscular injection of $75 \mathrm{mg}$ and oral administration of $150 \mathrm{mg}$ of active drug. Z Rheumatol. 1988; 47(1):37-42.
39- Lima EM, Oliveira AG. Tissue tolerance of diclofenac sodium encapsulated in liposomes after intramuscular administration. Drug Dev Ind Pharm. 2002; 28(6):673-80.

40- Souza SMB, Oliveira ON, Scarpa MV, et al. Study of the diclofenac/phospholipid interaction with liposomes and monolayers. Colloids Surfaces. 2004; 36(1):13-7.

41- Lopes LB, Scarpa MV, Pereira NL, et al. Interaction of sodium diclofenac with freezedried soya phosphatidylcholine and unilamellar liposomes. Rev Bras Cienc Farm. 2006; 42(4):497-504.

42- Faucher L, Marcoux D. What syndrome is this? Nicolau syndrome. Pediatr Dermatol. 1995; 12:187-90.

43- Paulsen $G$, Enger IM, Drange $M$, et al. A COX-2 inhibitor reduces muscle soreness, but does not influence recovery and adaptation after eccentric exercise. Scand $\mathrm{J}$ Med Sci Sports. 2010; 20(1):e195-e207.

44- Novak ML, Billich W, Smith SM, et al. COX-2 inhibitor reduces skeletal muscle hypertrophy in mice. Am J Physiol Regul Integr Comp Physiol. 2009; 296:R1132-R1139. 